\title{
道路橋床版の輪荷重直下の応力の算定について \\ ON EVALUATION OF STRESSES UNDER WHEEL LOADING FOR ROAD BRIDGE DECK SLABS
}

\author{
園田恵一郎*・堀川都 志雄** \\ By Keiichiro SONODA and Toshio HORIKAWA
}

\section{1.まえがき}

最近，道路橋鉄筋コンクリート床版において，過大な ひびわれやコンクリートの部分的なはく落等による損傷 が多く見られるようになった.このような損傷の原因 は, 交通荷重の増大, 繰り返し荷重による疲労, 施工不 良, コンクリートの乾燥収縮等いろいろといわれている が, 新しい床版が竣工後数年にして, 使用に支障をきた すほど劣化するといら事実にかんがみれば，鉄筋コンク リート床版（以下， R C 床版とよぶ）の従来の設計法に も大きな問題が潜んでいるように思われる ${ }^{1)}$.

わが国の道路橋示方書で規定された $\mathrm{RC}$ 床版の設計法 は, 主として曲げ耐荷力に注目している. 寸でに昭和 40 年ごろより, R C 床版の損傷がクローズアップされ て以来, 道路橋示方書の設計公式の問題点が指摘されて きた ${ }^{2) \sim 5)}$.

それらを挙げると, (1) 配力鉄筋量の不足, (2) 床版の たわみ剛性の不足, (3) 主桁の不等沈下の影響などであ り, それらの問題点の一部は, すでに現行の示方書 (昭 和 48 年度版) では配虑されている.

しかしながら, 実際の床版の損傷は, 自動車の走行に よって下面のひびわれが床版全体に抬がると同時に断面 内に進展することに伴って起こることが指摘されてい

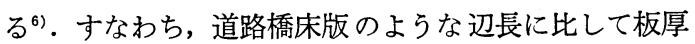
の小さい板構造においては, 自動車の輪荷重のような局 所的に集中した荷重の下では, 非常に大きな曲げモーメ ントが発生し, その值は荷重の作用面が小さくなればな るほど大きくなるといら特徴を持っている. したがっ て，比較的小さな輪荷重の作用下においてもひびわれが 入り, 輪荷重の移動とともにひびわれは床版全体に拡が るものと予想できる. 現行の道路橋示方書の設計曲げモ

$*$ 正会員 工博 大阪市立大学教授 工学部土木工学科

** 正会員 工修 大阪市立大学助手 工学部土木工学科
ーメント公式は,薄板弾性理論に基ざいており,輪荷重の 分布幅の取り方については，舗装表面でタイヤの接地圧 を $20 \times 50 \mathrm{~cm}^{2}$ の長方形等分布とし，舗装および床版の 厚みの $1 / 2$ を通して $45^{\circ}$ 方向に分散させ, 床版の中央 面で $(50+2 \times$ 舗装厚十床版厚 $) \times(20+2 \times$ 舗装厚十床版 厚) の長方形等分布荷重を仮定している.このようにタ イヤ接地圧を $45^{\circ}$ 方向に分散させる根拠は明確でなく, 戦前の古い示方書より慣習的に引き継がれてきたように 思われるが, 半無限体の表面に集中荷重が作用した場合 のブーシネスクの解に基づく鉛直応力の分布形からヒン トを得たものとも推測される7n.

すでに述べたように，局所的に集中した荷重を受ける 場合には，床版に作用する曲げモーメントは荷重の作用 面積の大きさに敏感に影響される.

本研究は,アスファルト舗装および $\mathrm{R} C$ 床版を 2 層弾 性板と見なし, 舗装表面に作用するタイヤの接地圧が床 版断面内にどのような応力および断面力を発生させるか を 3 次元弾性理論に基づいて調べたものである.

理論解析に用いた床版モデルは，ほぼ一方向板と見な せる辺長比が 1:3 の周辺単純支持板であり, アスファ ルト舗装とコンクリート床版は弾性係数の異なる板と見 なし，それらの接合面にはずれがなく，変位は完全に連 続するものと仮定した. なお，アスファルトを弾性体と 見なすことには疑問が残るが，主として走行自動車を対 象とした解析であるため容認されると思われる。

以上の床版モデルについての理論解析の結果より, 現 行の道路橋示方書で規定された荷重分布幅の取り方の妥 当性を検討するとともに, 実際に自動車の走行時に測定 されたタイヤの接地圧分布 ${ }^{8}$ に対する解析も行い, より 合理的な荷重分布幅の提案を試みた.さらに, 水圧を利 用した載荷実験を行い, 舗装と床版の間の鉛直応力分布 に関して実験值と計算值を比較し, 本理論解析法の信頼 性を検証した. 


\section{2. 解析のためのモデル化}

実際の床版は，主桁で弾性的に支えられ，また，コン クリート橋などでは, 横桁でも弾性的に支えられた構造 であり，桁と床版は剛に接合されている場合が多い.し かしながら, 本研究は, 後輪作用点近傍の局所応力の照 查を目的としており，曲げモーメントの大きい床版中央 部の局所応力特性に対しては, 床版の支持条件の影響を あまり受けないと考えられるため, 解析上の 床版モデ ルは, 図一1 に示すようなほぼ一方向板と見なせる辺長 比 $1: 3$ の単純支持板とした.

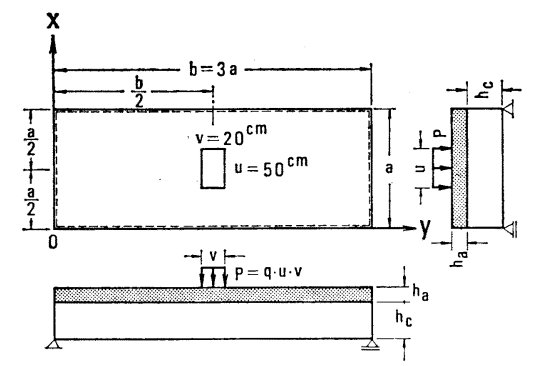

図一1 解析のためのモデル床版

舖装については, アスファルトを想定したが, 主とし て自動車の走行時を対象としたため，クリープ等の塑性 変形は無視し, 弾性体として取り扱った. また, 舗装と 床版との間にはずれがなく, 変位は完全に連続すると し, 全体の構造を 2 層弾性板と見なした.さらに, 温度 によるアスファルト舗装の影響は, 弾性係数を変化させ ることによって考慮した.

2 層弾性板の解析法として, 三次元弾性論に基づく厚 板理論を用い, 単純支持の条件は, ポアソン型の条件, すなわち支持辺に沿った鉛直および水平変位ならびに支 持辺に直角な方向の曲げモーメント, 軸力がいずれも零 である条件を，それぞれの板に対して用いた ${ }^{11), 12)}$.

以上の解析法において, 床版を弾性体として取り扱っ ているが，実際の床版では，ひびわれが入っている，し かしながら，自動車の走行によって，ひびわれは床版の ほぼ全体に拡がるので，ひびわれ先端における応力集中 の問題を除けば,ひびわれ床版は, 剛性が低下した均質 弾性体と近似的に見なすことができる，したがって，舗 装と床版の剛性比を操作することによって，ひびわれ床 版にも本解析法を適用させることができるものと思われ る.

\section{3. 三次元弾性論に基うく 2 層厚板の解析法}

ここで取り扱う床版は, 辺長に比して適度な板厚を持
つとし（辺長と板厚が同じオーダーであるものは除外）， 応力解析には厚板理論を適用する.

厚板理論における支持辺の条件は, 断面力または断面 変形量によって与えられるので,ここで用いた理論を, 3 次元弾性論におけるガラーキンベクトルとブーシネス ク関数の一成分によって構成する.

板の中央面に $x, y$ 軸をとり，中央面に鉛直下向きに $z$ 軸をとれば, ガラーキンベクトルとブーシネスク関数 の鉛直成分 $\left(F_{z}, \theta_{z}\right)$ と変位の関係および対応するつり 合い方程式は，下記のように表わされる ${ }^{9)}{ }^{12)}$.

$$
\left.\begin{array}{l}
2 G u=-\frac{\partial^{2} F_{z}}{\partial x \partial z}+2 \frac{\partial \theta_{z}}{\partial y} \\
2 G v=-\frac{\partial^{2} F_{z}}{\partial y \partial z}-2 \frac{\partial \theta_{z}}{\partial x} \\
2 G w=2(1-\nu) \Delta F_{z}-\frac{\partial^{2} F_{z}}{\partial z^{2}}
\end{array}\right\}
$$

ここに, $u, v, w$ は直交座標 $x, y, z$ 方向の変位, $G$ : せん断弾性係数.

周辺単純支持された 長方形板に対しては, 式 (2) の 関数 $F_{z}, \theta_{z}$ を薄板理論におけるレビー (Lévy) 解と同 様, $x, y$ 方向にはそれぞれ三角級数で, $z$ 方向には双 曲線関数で次のように表わす.

$$
\begin{aligned}
F_{z}= & \sum_{m} \sum_{n}\left[C_{1} \operatorname{sh} \gamma z+C_{2} \operatorname{ch} \gamma z+C_{3} \gamma z \operatorname{sh} \gamma z\right. \\
& \left.+C_{4} \gamma z \operatorname{ch} \gamma z\right] \sin \alpha_{m} x \sin \beta_{n} y \cdots \cdots \cdots(3) \\
\theta_{z}= & \sum_{m} \sum_{n}\left[C_{5} \operatorname{sh} \gamma z+C_{6} \operatorname{ch} \gamma z\right] \cos \alpha_{m} x \cos \beta_{n} y
\end{aligned}
$$

$こ こ に$

$$
\begin{aligned}
& \alpha_{m}=\frac{m \pi}{a}, \beta_{n}=\frac{n \pi}{b}, \\
& \gamma^{2}=\alpha_{m}{ }^{2}+\beta_{n}{ }^{2}, \operatorname{ch} \gamma z=\cosh \gamma z, \operatorname{sh} \gamma z=\sinh \gamma z,
\end{aligned}
$$
$a, b$ はそれぞれ $x, y$ 方向の辺長.

上式中 $C_{1} \sim C_{6}$ は積分定数で, 板の上・下面の境界条 件より決定する.

式 (1)より得られるひずみとフックの法則より, 応 力 $\sigma_{x}, \tau_{x y}, \tau_{x z}$ は次のようになる.

$$
\left.\begin{array}{l}
\sigma_{x}=\left(\nu \Delta-\frac{\partial^{2}}{\partial x^{2}}\right) \frac{\partial F_{z}}{\partial z}+2 \frac{\partial^{2} \theta_{z}}{\partial x \partial y} \\
\tau_{x y}=-\frac{\partial^{3} F_{z}}{\partial x \partial y \partial z}+\frac{\partial^{2} \theta_{z}}{\partial y^{2}}-\frac{\partial^{2} \theta_{z}}{\partial x^{2}} \\
\tau_{x z}=(1-\nu) \frac{\partial \Delta F_{z}}{\partial x}-\frac{\partial^{3} F_{z}}{\partial x \partial z^{2}}+\frac{\partial^{2} \theta_{z}}{\partial y \partial z}
\end{array}\right\}
$$

また, 他の応力 $\sigma_{y}, \sigma_{z}, \tau_{y z}$ は， $x, y, z$ をそれぞれ入 れ換えることによって得られる.さらに，モーメント $M_{x}, M_{y}, M_{x y}$, せん断力 $Q_{x}, Q_{y}$, 軸力 $N_{x}, N_{y}, N_{x y}$ は，上述の応力を積分することにより得られる. 


$$
\left.\begin{array}{l}
M_{x}=\int_{-h / 2}^{h / 2} \sigma_{x} z d z, M_{y}=\int_{-h / 2}^{h / 2} \sigma_{y} z d z \\
M_{x y}=\int_{-h / 2}^{h / 2} \tau_{x y} z d z, Q_{x}=\int_{-h / 2}^{h / 2} \tau_{x z} d z \\
Q_{y}=\int_{-h / 2}^{h / 2} \tau_{y z} d z, N_{x}=\int_{-h / 2}^{h / 2} \sigma_{x} d z \\
N_{y}=\int_{-h / 2}^{h / 2} \sigma_{y} d z, N_{x y}=\int_{-h / 2}^{h / 2} \tau_{x y} d z
\end{array}\right\}
$$

ここで，hは板の厚さである.

次に, 板の下面において, $x, y, z$ 方向にそれぞれ $X^{l}$, $Y^{l}, Z^{l}$ なる強度をもつ荷重が, また上面において, そ れらと逆方向の荷重 $X^{u}, Y^{u}, Z^{u}$ が作用するとし, 積分 定数 $C_{1} \sim C_{6}$ を求めると, 次のようになる.

$$
\begin{aligned}
C_{1}= & \frac{\bar{Z}_{p}}{2 r^{3} \operatorname{ch} \zeta} \cdot \frac{\zeta \mathrm{ct} \zeta+2 \nu}{D_{p}} \\
& -\frac{\beta_{n} \bar{Y}_{m}+\alpha_{m} \bar{X}_{m}}{2 r^{4} \operatorname{sh} \zeta} \cdot \frac{\zeta \operatorname{tn} \zeta-(1-2 \nu)}{D_{p}} \\
C_{2}= & \frac{\bar{Z}_{m}}{2 r^{3} \operatorname{sh} \zeta} \cdot \frac{\zeta \operatorname{tn} \zeta+2 \nu}{D_{m}} \\
& -\frac{\beta_{n} \bar{Y}_{p}+\alpha_{m} \bar{X}_{p}}{2 r^{4} \operatorname{ch} \zeta} \cdot \frac{\zeta \operatorname{ct} \zeta-(1-2 \nu)}{D_{m}} \\
C_{3}= & -\frac{\bar{Z}_{m}}{2 r^{3} \operatorname{sh} \zeta} \cdot \frac{1}{D_{m}}+\frac{\beta_{n} \bar{Y}_{p}+\alpha_{m} \bar{X}_{p}}{2 r^{4} \operatorname{ch} \zeta} \cdot \frac{1}{D_{m}} \\
C_{4}= & -\frac{\bar{Z}_{p}}{2 r^{3} \operatorname{ch} \zeta} \cdot \frac{1}{D_{p}}+\frac{\beta_{n} \bar{Y}_{m}+\alpha_{m} \bar{X}_{m}}{2 r^{4} \operatorname{sh} \zeta} \cdot \frac{1}{D_{p}} \\
C_{5}= & -\frac{\beta_{n} \bar{X}_{p}-\alpha_{m} \bar{Y}_{p}}{2 \gamma^{3} \operatorname{ch} \zeta} \\
C_{6}= & -\frac{\beta_{n} \bar{X}_{m}-\alpha_{m} \bar{Y}_{m}}{2 r^{3} \operatorname{sh} \zeta}
\end{aligned}
$$

$こ こ に$

$$
\begin{aligned}
& D_{m}=\zeta(\operatorname{ct} \zeta-\operatorname{tn} \zeta)-1, D_{p}=\zeta(\operatorname{tn} \zeta-\operatorname{ct} \zeta)-1, \\
& \text { ct } \zeta=\operatorname{coth} \zeta, \operatorname{tn} \zeta=\tanh \zeta, \zeta=r h / 2, \\
& \bar{X}_{p}=\bar{X}^{l}+\bar{X}_{u}, \bar{X}_{m}=\bar{X}^{l}-\bar{X}_{u}, \bar{Y}_{p}=\bar{Y}^{l}+\bar{Y}_{u} \\
& \bar{Y}_{m}=\bar{Y}^{l}-\bar{Y}_{u}, \bar{Z}_{p}=\bar{Z}^{l}+\bar{Z}_{u}, \bar{Z}_{m}=\bar{Z}^{l}-\bar{Z}_{u}
\end{aligned}
$$

$\bar{X}^{l}, \cdots, \bar{Z}_{u}$ は, それぞれ $X^{l}, \cdots, Z_{u}$ を 2 重フーリエ 級数で展開したときの係数, すなわち,

$$
X^{l}=\sum_{m} \sum_{n} \bar{X}^{l} \cos \alpha_{m} x \sin \beta_{n} y, \cdots
$$

である.

これらの積分定数 $C_{1} \sim C_{6}$ を応力, 変位, 断面力の式 (3)，(4)，(1)，(5)，(6) に代入すれば, 上・下面に種々 の外荷重が作用する場合の 3 次元弾性解が得られる.

次に，材質の異なる弾性板が，完全に接合 $(x, y, z$ 方向の変位 $u, v, w$ が完全に連続する) されている 2 層板を考え, 式 (1)〜 (7) をおのおのの板に適用し, 上 層板（アスファルト舗装）と下層板（ $\mathrm{R} \mathrm{C}$ 床版）との応 力, 変位の連続条件を次のように与える. なお, 添字 $u, l$ は，それぞれの板の上・下面を意味する.

応力の連続条件 ;

$$
\left.\begin{array}{l}
{\left[\tau_{x z}{ }^{l}\right]_{z=h_{a} / 2}=\left[\tau_{x z u}\right]_{z=-h_{c} / 2}} \\
{\left[\tau_{y z}{ }^{l}\right]_{z=h_{a} / 2}=\left[\tau_{y z u}\right]_{z=-h_{c} / 2}} \\
] \sigma_{z}{ }^{l}\right]_{z=h_{a} / 2}=\left[\sigma_{z u}\right]_{z=-h_{c} / 2}
\end{array}\right\}
$$

変位の連続条件;

$$
\left.\begin{array}{l}
{\left[u^{l}\right]_{y=h_{a} / 2}=\left[u_{u}\right]_{z}=-h_{c} / 2} \\
{\left[v^{l}\right]_{z=h_{a} / 2}=\left[v_{u}\right]_{z=-h_{c} / 2}} \\
{\left[w^{l}\right]_{z=h_{a} / 2}=\left[w^{u}\right]_{z=-h_{c} / 2}}
\end{array}\right\}
$$

ここに, $h_{a}$ : 上層板の厚さ, $h_{c}$ : 下層板の厚さ.

式 (8)，(9) を用いて，接合面で 6 つの連続条件式と， 2 層板の上・下面でそれぞれ 3 つの応力境界条件式とを 連立に解けば, それぞれの板における積分定数 $C_{1}{ }^{i} \sim C_{6}{ }^{i}$ (i=1,2）が決定できる.しかしながら，このままでは， 連立方程式の元数が 6 になるので, 級数の高次項におけ る計算誤差が大きくなり，十分な精度をもつ解を得るこ とは，困難になる．それゆえ，接合面間で伝達される力 を $X, Y, Z$ とし, おのおのの板における上・下面の変 位 $u, v, w$ を $X, Y, Z$ を用いて表わし, それらを式 (9) の変位の連続条件式に代入することによって, 未知 力 $X, Y, Z$ を求める. この方法によれば, 連立方程式 の元数は 3 となり, 計算も容易になる.

上層の鉛直荷重が作用する場合の未知力 $X, Y, Z$ を 求める式は, おのおののフーリエ級数の項数に対して次 式のように与えられる.

$$
\left[\begin{array}{c}
a_{11}, a_{12}, a_{13} \\
a_{12}, a_{22}, a_{13} \\
a_{13}, a_{13}, a_{33}
\end{array}\right]\left[\begin{array}{c}
\frac{\alpha_{m}}{r} X \\
\frac{\beta_{m}}{r} Y \\
Z
\end{array}\right]=\left[\begin{array}{l}
b_{1} \\
b_{1} \\
b_{2}
\end{array}\right]
$$

ここに,

$$
\begin{aligned}
a_{11}= & \frac{1}{2 G_{a}}\left[\left(1-\nu_{a}\right)\left(\frac{\operatorname{tn} \zeta_{a}}{D_{m a}}+\frac{\operatorname{ct} \zeta_{a}}{D_{p a}}\right)\right. \\
& \left.-\frac{\beta_{n}^{2}}{\alpha_{m}{ }^{2}}\left(\operatorname{tn} \zeta_{a}+\operatorname{ct} \zeta_{a}\right)\right] \\
& +\frac{1}{2 G_{c}}\left[\left(1-\nu_{c}\right)\left(\frac{\operatorname{tn} \zeta_{c}}{D_{m c}}+\frac{\operatorname{ct} \zeta_{c}}{D_{p c}}\right)\right. \\
& \left.-\frac{\beta_{n}{ }^{2}}{\alpha_{m}^{2}}\left(\operatorname{tn} \zeta_{c}+\operatorname{ct} \zeta_{c}\right)\right], \\
a_{12}= & \frac{1}{2 G_{a}}\left[\left(1-\nu_{a}\right)\left(\frac{\operatorname{tn} \zeta_{a}}{D_{m a}}+\frac{\operatorname{ct} \zeta_{a}}{D_{p a}}\right)\right. \\
& \left.+\left(\operatorname{tn} \zeta_{a}+\operatorname{ct} \zeta_{a}\right)\right] \\
& +\frac{1}{2 G_{c}}\left[\left(1-\nu_{c}\right)\left(\frac{\operatorname{tn} \zeta_{c}}{D_{m c}}+\frac{\operatorname{ct} \zeta_{c}}{D_{p c}}\right)\right. \\
& \left.+\left(\operatorname{tn} \zeta_{c}+\operatorname{ct} \zeta_{c}\right)\right] \\
a_{13}= & \frac{1}{2 G_{a}}\left[1+\left(1-\nu_{a}\right)\left(\frac{1}{D_{m a}}+\frac{1}{D_{p a}}\right)\right] \\
& -\frac{1}{2 G_{c}}\left[1+\left(1-\nu_{c}\right)\left(\frac{1}{D_{m c}}+\frac{1}{D_{p c}}\right)\right] \\
a_{22}= & \frac{1}{2 G_{a}}\left[\left(1-\nu_{a}\right)\left(\frac{\operatorname{tn} \zeta_{a}}{D_{m a}}+\frac{\operatorname{ct} \zeta_{a}}{D_{p a}}\right)\right. \\
&
\end{aligned}
$$




$$
\begin{aligned}
& \left.-\frac{\alpha_{m}^{2}}{\beta_{n}^{2}}\left(\operatorname{tn} \zeta_{a}+\operatorname{ct} \zeta_{a}\right)\right] \\
& +\frac{1}{2 G_{c}}\left[\left(1-\nu_{c}\right)\left(\frac{\operatorname{tn} \zeta_{c}}{D_{m c}}+\frac{\operatorname{ct} \zeta_{c}}{D_{p c}}\right)\right. \\
& \left.-\frac{\alpha_{m}^{2}}{\beta_{n}^{2}}\left(\operatorname{tn} \zeta_{c}+\operatorname{ct} \zeta_{c}\right)\right] \\
& a_{33}=\frac{1}{2 G_{a}}\left[\left(1-\nu_{a}\right)\left(\frac{\operatorname{ct} \zeta_{a}}{D_{m a}}+\frac{\operatorname{tn} \zeta_{a}}{D_{p a}}\right)\right] \\
& +\frac{1}{2 G_{c}}\left[\left(1-\nu_{c}\right)\left(\frac{\operatorname{ct} \zeta_{c}}{D_{m c}}+\frac{\operatorname{tn} \zeta_{c}}{D_{p c}}\right)\right] \\
& b_{1}=\frac{\bar{p}_{0}}{2 G_{a}}\left[\left(1-\nu_{a}\right)\left(\frac{1}{D_{m a}}-\frac{1}{D_{p a}}\right)\right] \\
& b_{2}=\frac{\bar{p}_{0}}{2 G_{a}}\left[\left(1-\nu_{a}\right)\left(\frac{\operatorname{ct} \zeta_{a}}{D_{m a}}-\frac{\operatorname{tn} \zeta_{a}}{D_{p a}}\right)\right] \\
& \zeta_{a}=\frac{r h_{a}}{2}, \zeta_{c}=\frac{r h_{c}}{2} \\
& D_{m a}=\zeta_{a}\left(\operatorname{ct} \zeta_{a}-\operatorname{tn} \zeta_{a}\right)-1 \\
& D_{p a}=\zeta_{a}\left(\operatorname{tn} \zeta_{a}-\operatorname{ct} \zeta_{a}\right)-1 \\
& D_{m c}=\zeta_{c}\left(\operatorname{ct} \zeta_{c}-\operatorname{tn} \zeta_{c}\right)-1 \\
& D_{p c}=\zeta_{c}\left(\operatorname{tn} \zeta_{c}-\operatorname{ct} \zeta_{c}\right)-1
\end{aligned}
$$

$G_{a}, G_{c}$ : 上層板（アスファルト舗装）および下層板 ( R C 床版) のせん断弾性係数,

$\nu_{a}, \nu_{c}$ : 上層板および下層板のポアソン比,

$\bar{p}_{0}$ : 上層板の上面に作用する鉛直荷重 $p_{0}$ のフ 一リエ係数,

さらに, 式 (7) の積分定数 $C_{1}{ }^{i} \sim C_{6}{ }^{i}(i=1,2)$ に代入 すると, 各層の応力, 断面力などが得られる.

\section{4. 数値解析の検討}

\section{（1） 解の収束性}

荷重としては, 道路橋示方書 (昭和 48 年度版) で規 定された後輪荷重 $\left(20 \times 50 \mathrm{~cm}^{2}\right.$ の長方形等分布荷重)を 用い,この荷重を 2 重フーリエ級数によって表示した.

フーリエ級数は, 無限級数であるから, 項数を多くと ればとるほど, 解析の精度が上がることになる が, 計算時間および労力の関係上, 一定の有限項 に止めなければならない. 下記の諸元をもつ床版 に対して (図一1 参照)

$$
\begin{aligned}
& a=2.0 \mathrm{~m}, E_{a}=1.0 \times 10^{4} \mathrm{~kg} / \mathrm{cm}^{2} \\
& b=6.0 \mathrm{~m}, E_{c}=30.0 \times 10^{4} \mathrm{~kg} / \mathrm{cm}^{2} \\
& h_{a}=5 \mathrm{~cm}, \nu_{a}=0.4 \\
& h_{c}=17 \mathrm{~cm}, \nu_{c}=0.16
\end{aligned}
$$

ここに, 添字 $a, c$ は, アスファルト舗装および $\mathrm{R}$ C 床版を意味する.

荷重面中心の接合面および床版中央のたわみ, 面内および面外方向の直応力の計算值と級数の項

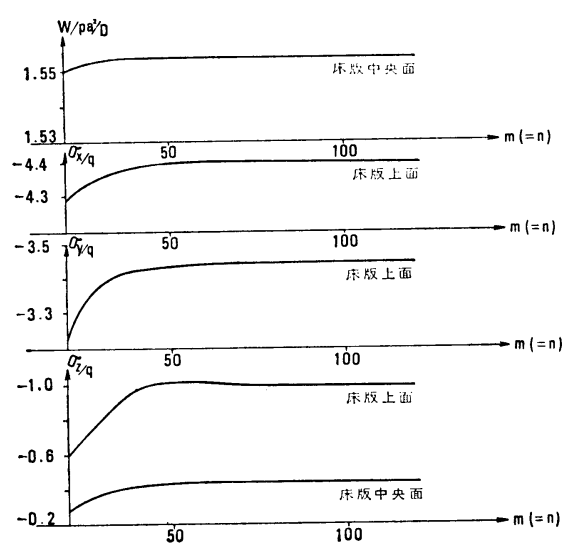

図-2 級数の項数 $(m, n)$ による䇅荷面中央の たわみおよび応力の収束状況

数（2 重級数の $x, y$ 方向の項数は同じものとした）と の関係を 図一2 に示した.

一般に, 荷重作用面に近い位置の応力の精度が級数の 項数に一番影響されやすく, 断面力, たわみ等は, 同じ 項数の下では応力よりはるかに精度がよくなるので, 図 -2 より判断すれば, 60 項以上とれば, 十分に信頼で きる計算結果が得られるものと推測できる.

\section{（2）荷重面下の応力分布}

荷重面直下の 鉛直応力 $\left(\sigma_{z}\right)$ の 分布形を 図一3 に示 す.これは, 級数の項数 91 による結果である.

荷重接触面では, 端部において脈動しているが, これ は矩形波の級数展開におけるギッブスの現象であり，こ の点を除けば, 応力分布は非常になめらかであり, 荷重 面から遠ざかるにつれて, その強度は減少していること がわかる. 一方, 荷重面近傍の断面における床版の面内 方向の応力 $\left(\sigma_{x}, x\right.$ は支間方向) の分布を 図一4に示す が, この程度の板厚/スパン比 $\left(h_{c} / a=0.085\right)$ では, ほ とんど直線分布に近く, 舗装接合面での圧縮応力の集中 はごくわずか見られるのみである.

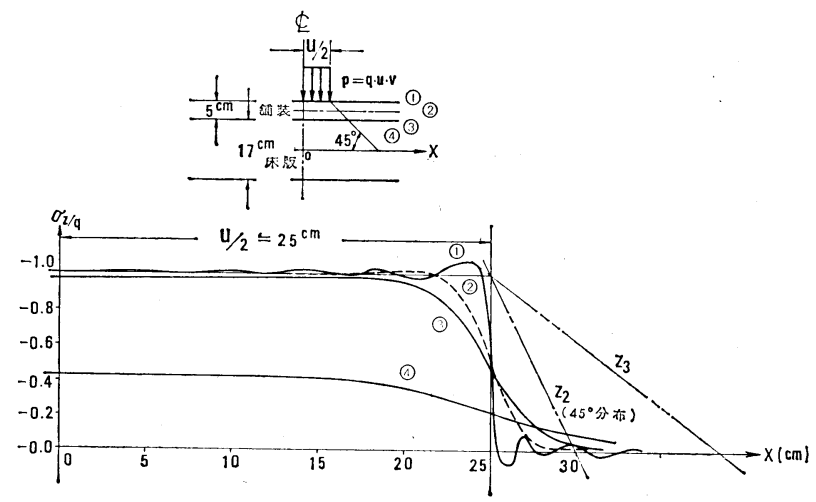

図-3 荷重面直下の $\sigma_{z} / \boldsymbol{q}$ の分布形 $(y=b / 2$ 断面 $)$ 

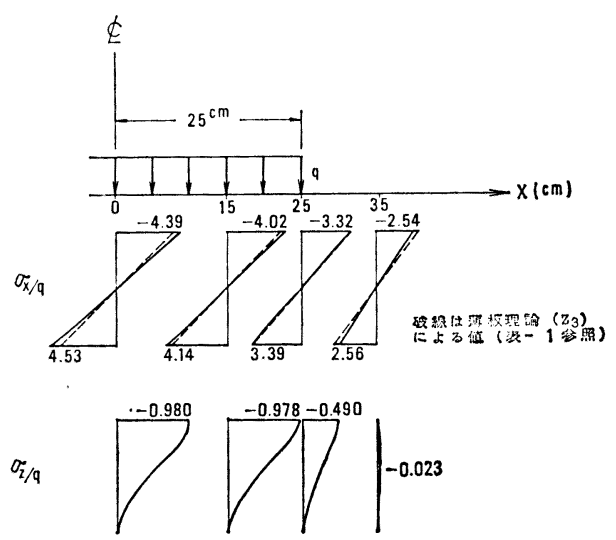

図-4 荷臬面近傍の床版の态力分布 $(y=b / 2$ 断面 $)$

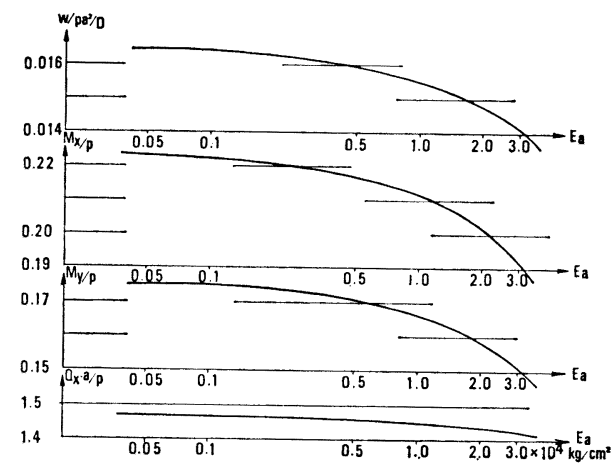

図一5 舗装材の弾性保数の変動によるたわみ, モーメントおよび せん断力の変化 $(y=$ $b / 2$ 断面)

次に, 舗装材の弾性係数の変動の及ぼす影響について 考える. アスファルトのような舗装材は, 夏期と冬期で はその剛性は大きく変化する. 文献 13）によれば, 厳冬 期ではアスファルトの弾性係数は, $3.0 \times 10^{4} \mathrm{~kg} / \mathrm{cm}^{2}$ 程 度であり，災天下では非常に低く $0.05 \times 10^{4} \mathrm{~kg} / \mathrm{cm}^{2}$ 以 下になることもあるといわれている. 図一5 は, 式 (11) の諸元の床版についての計算結果より, 舗装材の弾性係 数と載荷面中央のたわみおよび断面力の関係を示したも

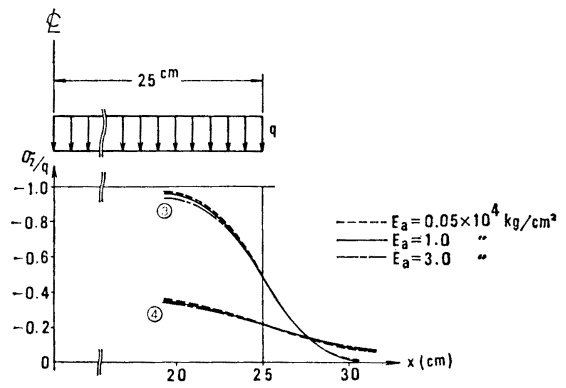

図一6 舖装材の弾性係数の変動による $\sigma_{z} / \boldsymbol{q}$ の分布形の変化 $(y=b / 2$ 断面, 図一3 参照)
のである.この結果によれば, 峳冬期に比して夏期で は, たわみおよびモーメントとも $16 \%$ 程度増加するこ とになる.この増加量は, 主として舗装材自身の抵抗力 の減少によって起こる分であり, 舗装材の剛性が, 荷重 の分散に与える 影響は ほとんどないようである（図一6 参照).

したがって, 床版の設計計算上, 舗装材に発生する応 力を無視するならば, 路面上の荷重の 舗装内での 分散 は舗装の剛性によってほとんど影響されないといえる.

\section{5. 道路橋示方書における輪荷重分布幅につい ての検討}

現行の道路橋示方書 (昭和 48 年度版) の設計曲げモ 一メントは, 車道部橋軸方向に 1 台, 幅方向には, 着目 点の曲げモーメントが最大になるように何台かを載せ， 主桁で支えられた帯状板として薄板理論に基づいて算定 されている.しかしながら, 通常の支間長（主桁間隔） では, 床版の設計において最も重要と思われる支間中央 の正の最大曲げモーメントは, 支間中央に位置する後輪 荷重によって支配され, 他の輪荷重の影響は, わずかで あると考えられる. 局所荷重点下の曲げモーメントを 薄板理論により 算定する場合, 荷重值は同じであって も，その分布形状に大きく影響されることは，周知のと おりである ${ }^{14)}$. 現行道路橋示方書・同解説では, 舖装表 面に $20 \times 50 \mathrm{~cm}^{2}$ の大きさの等分布荷重が作用し, それ が舗装厚 $(5 \mathrm{~cm})$ および床版厚の $1 / 2$ まで $45^{\circ}$ 方向に 一様に分布すると仮定し, 薄板の理論計算に用いる荷重 としては $(50+2 \times 5+$ 床版厚 $) \times(20+2 \times 5+$ 床版厚 $)$ の 等分布荷重を採用している. また, 現行のコンクリート 標準示方書 (昭和 49 年度版) でも, 集中的な荷重の分 布幅の取り方は，同じ考えに基づいている.このような $45^{\circ}$ 方向に荷重を分散させる根拠は, 明確でなく, おそ らく集中荷重を受けた半無限体の鉛直方向応力の分布形 から類推して, 慣習的に決められたものと思われる.

さて，本研究では，3. で述べたように，道路橋 R C 床版を 2 層弾性板として取り扱い, 上述の輪荷重分布幅 の取り方について検討する.

舗装材および床版の諸元が，

$$
\left.\begin{array}{l}
E_{a}=1.0 \times 10^{4} \mathrm{~kg} / \mathrm{cm}^{2}, \nu_{a}=0.4, h_{a}=5 \mathrm{~cm} \\
E_{c}=30.0 \times 10^{4} \mathrm{~kg} / \mathrm{cm}^{2}, \nu_{c}=0.16
\end{array}\right\}
$$

であるような床版 (図一1 参照) を取り上げ, 図一7に 示すごとく, 2 層弾性板としての 3 次元解析 $\left(D_{1}\right)$ と現 行の示方書による荷重分布 $\left(Z_{3}\right)$ そして, まったく荷重 分散を考えない場合 $\left(Z_{1}\right)$, 舗装部のみ $45^{\circ}$ 方向分散を 考えた場合 $\left(Z_{2}\right)$ による薄板理論解析とのそれぞれを比 


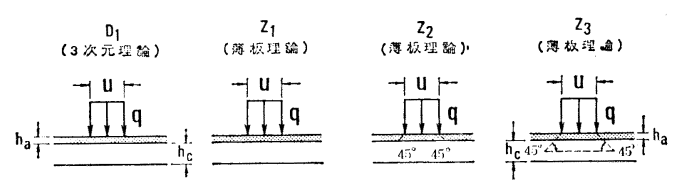

図一7 荷重の状態 $(u=50 \mathrm{~cm}, v=20 \mathrm{~cm})$

表一1 たわみ, モーメントおよびせん断力の比較 $(P=q u v)$

\begin{tabular}{|c|c|c|c|c|c|}
\hline & $a^{(m)}$ & 1.0 & 2.0 & 3.0 & 4.0 \\
\hline & $h_{c}^{(\mathrm{cm})}$ & 16 & 17 & 20 & 23 \\
\hline \multirow{4}{*}{$\begin{array}{r}(W)_{\max } \\
\left(\times \frac{P \cdot a^{2}}{D}\right)\end{array}$} & $D_{1}$ & 0.0143 & 0.0156 & 0.0161 & 0.0163 \\
\hline & $Z_{1}$ & 0.0144 & 0.0167 & 0.0165 & 0.0167 \\
\hline & $\mathrm{Z}_{2}$ & 0.0134 & 0.0158 & 0.0164 & 0.0166 \\
\hline & $\mathrm{Z}_{3}$ & 0.0117 & 0.0151 & 0.0159 & 0.0163 \\
\hline \multirow{4}{*}{$\begin{array}{c}\left(M_{x}\right)_{\max } \\
(\times p)\end{array}$} & $D_{1}$ & 0.149 & 0.212 & 0.250 & 0.278 \\
\hline & $\mathrm{Z}_{1}$ & 0.168 & 0.233 & 0.271 & 0.296 \\
\hline & $Z_{2}$ & 0.147 & 0.213 & 0.251 & 0.278 \\
\hline & $Z_{3}$ & 0.121 & 0.187 & 0.221 & 0.237 \\
\hline \multirow{4}{*}{$\begin{array}{c}\left(\mathrm{M}_{y}\right)_{\max } \\
(\times \mathrm{P})\end{array}$} & $\mathrm{D}_{1}$ & 0.107 & 0.167 & 0.201 & 0.224 \\
\hline & $Z_{1}$ & 0.134 & 0.196 & 0.234 & 0.257 \\
\hline & $Z_{2}$ & 0.108 & 0.173 & 0.211 & 0.244 \\
\hline & $Z_{3}$ & 0.077 & 0.740 & 0.172 & 0.195 \\
\hline \multirow{4}{*}{$\begin{array}{r}\left(0_{x}\right)_{\max } \\
\left(\times \frac{p}{a}\right)\end{array}$} & $D_{1}$ & 0.78 & 1.45 & 2.16 & 2.82 \\
\hline & $Z_{1}$ & 0.90 & 1.67 & 2.48 & 3.21 \\
\hline & $Z_{2}$ & 0.73 & 1.28 & 1.88 & 2.52 \\
\hline & $Z_{3}$ & 0.59 & 0.94 & 1.31 & 1.59 \\
\hline
\end{tabular}

較する。

支間長と板厚の関係は，示方書で示されたもの（道路 橋示方書・同解説, pp. 173, 図一解 6.1.3 参照) 用い 上記の各ケースについての計算結果を 表一1 に示す.

また, 支間 $2.0 \mathrm{~m}$, 板厚 $17 \mathrm{~cm}$ の床版の モデルにつ いて, 荷重中心をと晾る支間方向のモーメントおよびせ 儿断力の分布を 図一8〜10 に示す.

これらの計算結果により下記のことが明らかになる。

（1）道路橋示方書で示された荷重分布幅に対する結 果 (以下, 示方書による値とよぶ) は，3 次元厚板理論 によるそれと，たわみに関してはほとんど変らない。

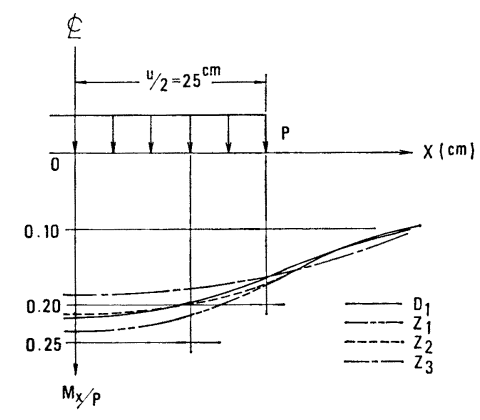

図一8 支間方向のモーメント分布 $\left(\boldsymbol{M}_{x}\right)$ の比較 $(y=b / 2$ 断面)

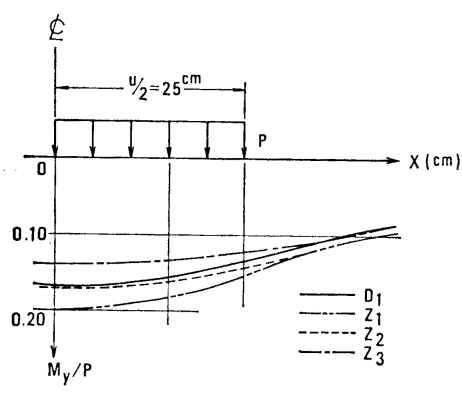

図一9支間と直角方向のモーメント分布 $\left(\boldsymbol{M}_{y}\right)$ の比較 $(y=b / 2$ 断面 $)$

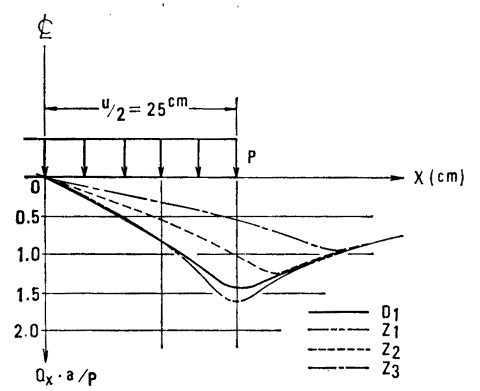

図一10 支間方向のせん断力分布 $\left(\boldsymbol{Q}_{x}\right)$ の比較 $(y=b / 2$ 断面)

（2）支間方向（主筋方向）の曲げモーメント $\left(M_{x}\right)$ に関しては, 示方書による值は, 3 次元理論による值よ り 15〜19\% ほど小さい.

（3）支間と直角方向（配力筋方向）の曲げモーメン 卜 $\left(M_{y}\right)$ に関しては, 示方書による值は, 3 次元理論に よる值より 13〜28\% ほど小さい.

（4）せん断力 $\left(Q_{x}\right)$ の最大は, 荷重分布の端部で 起こり, その值に関して, 示方書による值は, 3 次元理 論による值より $25 \sim 44 \%$ ほど小さく, その比は支間長 が大きくなるにつれて増大している.

（5）モーメントおよびせん断力に関して示方書によ る值と 3 次元理論による值との差は, 荷重面中央または 端部において最も大きく, 荷重面から遠ざかるにつれて 小さくなる.

（6）荷重の分散をまったく考えない場合 $\left(Z_{1}\right)$ での たわみ，モーメント，せん断力は，いずれも 3 次元理論 による值より大きい.

（7）舗装部のみ $45^{\circ}$ 方向に分散させた場合 $\left(Z_{2}\right)$ の 結果は, 3 次元理論による值と最も近くモーメントの值 では, その差は 1〜9\% に留まっている.

以上の結果より, 現行の示方書で規定されている後輪 荷重の舗装および床版内での $45^{\circ}$ 方向への分散は期待で きず，それゆえ荷重面直下のモーメントおよびせん断力 の算定に対して現行の示方書の計算方法による值は, か なり小さな值を与えることがわかる. 


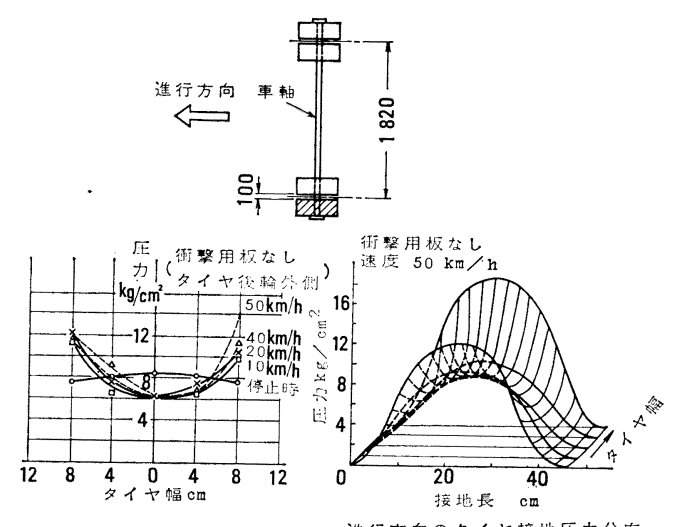

タイヤ幅方向の压力分有

连行方向のタイヤ接地压力分有

図一11 実測によるタイヤの接地圧力分布

\section{6. 実測によるタイヤ接地圧分布の下での床版 応力の検討}

道路橋示方書で規定された後輪荷重は, $20 \times 50 \mathrm{~cm}^{2}$ の 長方形等分布荷重であるが, 実際の自動車の静止または 走行時の タイヤの接地圧力分布は複雑である. 図一11 は貞升により計測されたタイヤの接地圧力分布形であ る $^{8)}$. 実測された接地圧力分布形を $y$ 方向（支間と直角 方向）に対しては，4次曲線で， $x$ 方向（支間方向）に は，2 次曲線で示される関数形であてはめ,さらにその 関数形を 3. と同様フーリエ級数に展開し, タイヤ $2 つ$ 分の後輪荷重をアスファルト舗装の表面に作用させ， 3 次元理論により, 走行時および停止時の 2 つの場合につ いて断面力計算を行った. 計算に用いた床版の諸元は, $a=2.0 \mathrm{~m}, b=6.0 \mathrm{~m}, h_{c}=17 \mathrm{~cm}, h_{a}=5 \mathrm{~cm}, E_{c}=30.0$ $\times 10^{4} \mathrm{~kg} / \mathrm{cm}^{2}, E_{a}=1.0 \times 10^{4} \mathrm{~kg} / \mathrm{cm}^{2}, \nu_{c}=0.16, \nu_{a}=0.4$ である.停止時の接地圧力分布の $y$ 方向の形状は, 貞升の 論文の中では不明であるので, 車の走行速度が $20 \mathrm{~km} / \mathrm{h}$ 時のものを用いた。これらの計算結果と表一1 の載荷 状態との比較を 表一2 に示す. ただし, 後輪のタイヤ は 2 個であり, 全荷重 $(P)$ は, 2 つのタイヤで均等に 分担されるものとし, タイヤ縁部の外側と内側の接地圧 力は等しいとした.

走行時 $(50 \mathrm{~km} / \mathrm{h})$ における計算結果を $D_{1}$ による結果 と比較すると, たわみ $(w)$, モ一メント $\left(M_{x}\right),\left(M_{y}\right)$,

表一2 実測されたタイヤ接地圧に対する版の 最大たわみ, 最大モーメントおよび最大 せん断力の比較

\begin{tabular}{|l|c|c|c|c|}
\hline & $\mathrm{D}_{1}$ & $\mathrm{Z}_{3}$ & $\begin{array}{c}\text { 走行時 } \\
(50 \mathrm{~km} / \mathrm{h})\end{array}$ & 停止時 \\
\hline$(\mathrm{W})_{\max }\left(\times \frac{\mathrm{Pa}}{\mathrm{D}}\right)$ & 0.0156 & 0.0151 & 0.0151 & 0.0130 \\
\hline$\left(\mathrm{M}_{\mathrm{X}}\right)_{\max }(\times \mathrm{P})$ & 0.212 & 0.187 & 0.197 & 0.175 \\
\hline$\left(\mathrm{M}_{\mathrm{y}}\right)_{\max }(\times \mathrm{P})$ & 0.167 & 0.140 & 0.151 & 0.148 \\
\hline$\left(\mathrm{O}_{\mathrm{x}}\right)_{\max }\left(\times \frac{\mathrm{P}}{\mathrm{a}}\right)$ & 1.45 & 0.94 & 1.32 & 1.35 \\
\hline
\end{tabular}

せん断力 $\left(Q_{x}\right)$ は，それぞれ $3,7,10,9 \%$ ほ ばさ く, 現行の道路橋示方書 $\left(Z_{3}\right)$ の場合と比較すると, た わみはほぼ等しく, モーメント, せん断力は, それぞれ 5，7，29\% ほど大きく, せん断力における増加量はか なり顕著である. 実際の路面での走行状態では, タイヤ の接地圧分布および 1 つのイヤが分担する荷重は, 路 面の特性によって大きく影響されるものと思われる．も し, 路面の凹凸がひどければ, 後輪の 1 つのタイヤに作 用する荷重は, 軸重 (後輪 2 つ分) の $1 / 4$ よりかなり 大きく, その結果, 荷重面值下のモーメントおよびせん 断力が相当大きくなることが予想できる.したがって， 走行時に 1 つのタイヤ作用する荷重の変動がどの程度 であるかを知ることが大切になるう。

\section{7. 実験結果}

舗装と床版の接合面に作用する鉛直応力を計測するた めに, $1.5 \times 1.5 \mathrm{~m}^{2}$, 厚さ $16 \mathrm{~cm}$ の R C 正方形単純支持 板を作成した.この床版の上面にストレインゲージタイ プの 圧力計 (外径 $2 \mathrm{~cm} \times$ 高さ $5 \mathrm{~mm}$ ) を約 $4.4 \mathrm{~cm} \mathrm{の}$ 間隔で配置し，その上に微量のセメントを混入した砂を 突き固めて $5 \mathrm{~cm}$ の厚さの舗装を作り, 舗装表面に正方 形等分布荷重を作用させて実験を行った. 舗装の弾性係 数については, 載荷面と同じ大きさの平板載荷実験を行 って, 約 $500 \mathrm{~kg} / \mathrm{cm}^{2}$ の值を得た. 載荷装置については, 図一12 に示すように木枠の中にゴム袋を入れ，上・下 面を拘束した状態で，ゴム袋の中に水圧を加えることに よって舗装面に等分布荷重を与えた．なお，荷重の検定 は，2 $\mathrm{t}$ 用のプルービングリングを用いて全荷重の值を 測定した. 結果を 図一13 に示す. 図中の実験值は, 載 荷面の位置を移動させて数回繰り返し, 舗装と床版の接 合面の鉛直応力分布の計測した結果の代表值を示してい る. 実験結果と舗装の弾性係数を $500 \mathrm{~kg} / \mathrm{cm}^{2}$ とした場 合の計算値を比較すると，両者は非常によく一致してい ることがわかる。

さらに, 破線（舗装のみ $45^{\circ}$ 分布した場合の載荷端 部）で示された箇所より外側の圧力計の值は，ほとんど 零を示しており, 計算值の妥当性を立証している.

\section{8. 結 論}

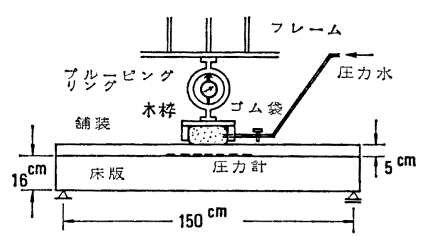

図一12 実 験 装 置 


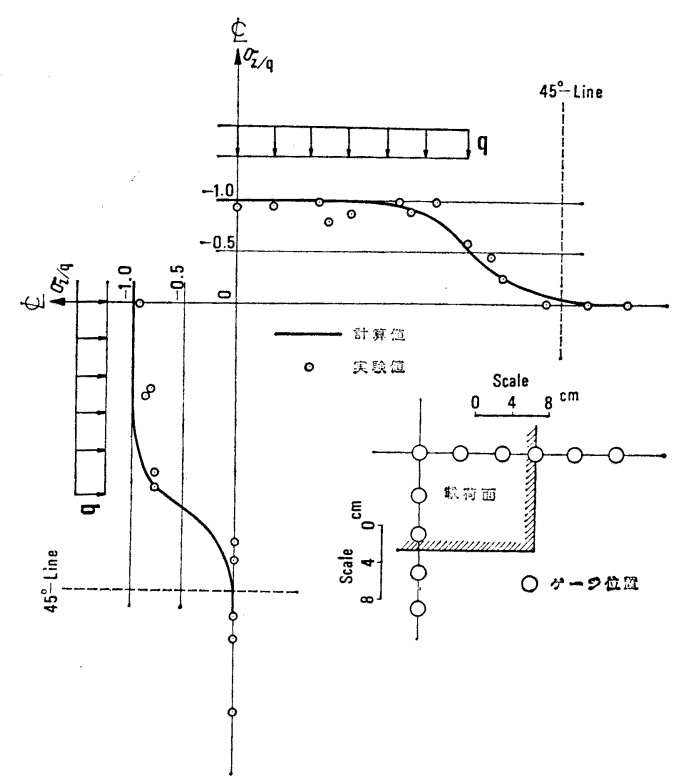

図一13 接合面上における $\sigma_{z} / q$ の比較

数值計算結果および実験結果をもとに得られた結論を 列記すると，

（1）夏期と冬期におけるアスファルト舗装の弾性係 数の変動は, せん断力に対してはほとんど影響を及ぼさ ないが，たわみと曲げモーメントに対して，かなりの影 響（モデル床版の計算では約 $16 \%$ の差）を与える.し かしながら，この影響は舗装材自身が応力を分担するこ とによって起こるものであり, 舗装の剛性が輪荷重の分 散に与える効果はほとんどない.

（2）現行の道路橋示方書・同解説に示されているよ うに舗装厚および床版厚の $1 / 2$ まで $45^{\circ}$ 方向に後輪荷重 を分散させた場合には，たわみ，曲げモーメントおよび せん断力とも三次元厚板理論による結果よりかなり小さ な值を与える．また，舗装厚のみ $45^{\circ}$ 方向に分散させた 場合には, 三次元厚板理論值と比べて，たわみと曲げモ ーメントはほぼ同じであるが，せん断力では小さくなっ ている.さらに，舖装，床版とも荷重分散をまったく考 えない場合では，3 次元理論による值よりたわみ・曲げ モーメ゙ントは大きいが, せん断力についてはほぼ同じ值 を与える。

（3）自動車走行時の下での実測されたタイヤ接地圧 力分布を用い, 3 次元厚板理論により計算された結果と 道路橋示方書・同解説による值とを比較すると,たわみ はほぼ同じであるが，モーメント，せん断力はそれぞれ $5,29 \%$ ほど大きく，特にせん断力における増加は顕著 である。

（4）舗装を微量のセメントを混入した砂で作り，水
圧の下での実験を行った結果，舗装と床版の接合面での 鉛直応力分布の実験値と計算値は, 非常によく一致して おり，本論文で用いた理論の妥当性が裏ゔけられた。

以上より 判断すれば， 道路橋 R C 床版の設計に際し て，現行の道路橋示方書・同解説で示された後輪荷重の 分布幅の取り方は，危険側の結果を与えるといえる.

曲げモーメントの算定に対しては, 舗装厚のみ $45^{\circ}$ 方 向に分散させた場合が最も合理的であるが，せん断力に 対しては，なお危険側の結果を与える.

したがって, 実際の床版では, 路面の凹凸によるタイ ヤ一輪に作用する荷重の変動および夏期における舗装の 剛性低下等が考えられるので, 設計において薄板理論に より断面力を算定する場合には舗装および床版とも輪荷 重の分散を考慮しない方が妥当であるものと思われる.

\section{参考文献}

1）土木学会関西支部：鉄筋コンクリート床版の損傷と疲労 設計へのアプローチ，土木学会関西支部講演会テキスト， 昭和 52 年 7 月.

2）佐藤 進・成岡昌夫：支持桁のたわみを考虑した鋼道路橋 の鉄筋コンクリートの床版の曲げモーメントについて, 土木学会論文報告集, No. 175, pp. 1 13, 1970 年 3 月.

3）前田幸雄・松井繁之：道路橋 R C 床版の設計曲げモーメ ソト式に関する一考察, 土木学会論文報告集, No. 252, pp. $11 \sim 22,1976$ 年 8 月.

4）国広哲男・井刚治久：床版支持桁の不等沈下によって生 ずる床版の曲げモーメント，土木技術資料，Vol. 13-1, 昭和 46 年 1 月.

5）国広哲男・井刘治久 - 伊藤 満 : 床版支持桁の不等沈下に よって生ずる床版の曲げモーメント計算図表，建設省土 木研究所資料, 第 771 号 (昭和 47 年 9 月), 第 875 号 (昭 和 48 年 9 月).

6）倉田宗章 - 園田恵一郎 - 実松秀夫 - 竹村泰弘：既設道路 $\mathrm{R}$ C床版の疲労破壊実験と疲労破壊機構に関する一考察, 第 22 回構造工学シンポジウム, 日本学術会議, pp. 63〜 70,1976 年 1 月.

7）田中 豊. 平井 敦 共著：鋼橋 I, 技報堂, pp. 250 257, 昭和 28 年.

8）貞升文槌：自動車走行時におけるタイヤ接地圧，土木技 術資料, Vol. 11, No. 8, pp. 3 5, 1969 年 8 月.

9) Westergaad, H.M. : Theory of Elasticity and Plasticity, Dover, New-York.

10）宮本 博: 三次元弾性論, 裳華房, pp. 16 19, 昭和 42 年.

11) Horikawa, T., Sonoda, K. and Kurata, M. : Studies of a finite deformation of plate due to Reissner's theory and three dimensional theory of thick. plate with body forces., Memo., Osaka City Univ., Vol. 15 , pp. $121 \sim 133,1974$.

12) Horikawa, T., Sonoda, K. and Kurata, M. : A comparison of numerical results given by thick plate, Reissner's and thin plate theories., Memo., Osaka City, Univ., Vol. 16, pp. 169 186, 1975.

13）笠原 篤・菅原照雄 : アスファルト混合物の動的応答に関 する研究，土木学会論文報告集，No. 215 , pp. $75 \sim 83$, 1973.

14) Nádai, A. : Elastishe Platten, Springer.

(1977.8.11 • 受付) 